\title{
Changes in soil phenol oxidase activities due to long-term application of compost and mineral $\mathrm{N}$ in a walnut orchard
}

\author{
Martina Mazzon, Luciano Cavani*, Alja Margon, Giovambattista Sorrenti, Claudio Ciavatta, Claudio Marzadori \\ Department of Agricultural Sciences, Alma Mater Studiorum University of Bologna, Viale Fanin 40, 40127 Bologna, (Italy)
}

\section{A R T I C L E I N F O}

\section{Keywords:}

Fertilization management

Soil depth

Specific enzyme activity

Soil fertility

Phenol oxidase activity

Soil organic matter turnover

\begin{abstract}
A B S T R A C T
Phenol oxidases (POs) are a group of soil extracellular oxidoreductase enzymes, which are involved in oxidative processes related to nutrient cycling. This class of enzymes has multiple functions at both the organism and ecosystem level and can trigger either positive or negative feedback loops between soil organisms and soil organic matter.

The purpose of this study was to evaluate: (i) whether PO activities have a trend different from those of microbial biomass and activity; and (ii) whether PO activities are enhanced or reduced by fertilizer application.

Soil samples were taken from plots in a 14-year-old experimental walnut orchard, subjected, since planting, to three fertilizer treatments: organic (compost) or mineral (urea) fertilization at the same rate of nitrogen application (100 kg N ha- ${ }^{-1}$ ), or left unfertilized. Soil samples were divided according to sampling depth $(0-20 \mathrm{~cm}$ and $20-40 \mathrm{~cm})$.

Results showed that the application of compost significantly increased $\mathrm{C}$ and $\mathrm{N}$ pools. $\mathrm{qCO}_{2}$ and $\mathrm{DHD} / \mathrm{C}_{\mathrm{ext}}$ data indicated that the biota at $20-40 \mathrm{~cm}$ soil depth was more stressed or mainly composed of microorganisms with low substrate utilization efficiency. Phenol oxidase, tyrosinase, and catechol oxidase activities were significantly promoted in the surface layer by compost addition. In contrast, laccase activity showed a large increase in the deeper soil layer when supplied with mineral $\mathrm{N}$, whereas compost addition led to increased activity in the surface layer. These findings suggest that soil phenol oxidases play a part in the determination of soil functionality, but they need to be investigated in greater depth in order to understand the mechanisms regulating their activities.
\end{abstract}

\section{Introduction}

Soil organic carbon (SOC) content is considered an essential factor in determining soil quality. Its decline can be counteracted and prevented effectively through the adoption of appropriate agricultural management practices (Lal 2004). One such widespread agronomic practice is nitrogen $(\mathrm{N})$ application. It affects microbial community composition and metabolic activity and can have long-term effects on the SOC cycle (Carreiro et al., 2000). Moreover, given the interconnection between soil $\mathrm{N}$ and carbon (C), external addition of $\mathrm{N}$ can also influence cellular $\mathrm{C}: \mathrm{N}$ stoichiometric ratios and soil ecological stoichiometry, thus leading to changes in C use efficiency (Finn et al. 2016).

Microbes react to changes in substrate availability (i.e. $\mathrm{C}$ or $\mathrm{N}$ excess/limitation) by increasing or decreasing their respiration rate, and using C to gain energy or to increase biomass (Spohn 2015).
Moorhead and Sinsabaugh (2006) proposed a classification of microorganisms involved in the decomposition of different litter pools: opportunists that are active in the early stage of decomposition, using the available litter directly; decomposers that degrade cellulose and lignocellulose by expressing both hydrolytic and oxidative enzymes; and miners that degrade humified organic matter by using oxidative enzymes (such as phenol oxidase) that are able to metabolize phenols and degrade the most recalcitrant pools. Therefore, microorganisms may regulate enzyme expression depending on decomposition stage or characteristics of the substrate present in the soil. Furthermore, soil enzymes may show considerable changes in activity and interaction with soil components, leading to changes in SOC turnover after disturbance due to management practices (Naseby and Lynch 2002). It should be highlighted that enzyme activities have the capacity to adapt to soil perturbations swiftly, and therefore they can be considered timely indicators of soil

\footnotetext{
* Corresponding author at: Viale Fanin 40, 40127 Bologna, (Italy)

Email address: luciano.cavani@unibo.it (L. Cavani)
} 
quality also in the case of small-scale disturbances (Cattaneo et al., 2014). In addition, it is important to underline that enzyme activity is controlled by not only availability and characteristics of soil substrates but also by abiotic conditions such as $\mathrm{pH}$, temperature, presence of heavy metals, and soil moisture. These abiotic conditions have an impact on microbial biomass, affecting enzyme production, kinetics, stability, and affinity for substrates (Rao et al. 2014). In general, the main reason for measuring hydrolytic enzyme activity is the role the enzymes play in mediating soil biochemical processes related to nutrient cycles (Giacometti et al. 2014). However, these processes are also controlled by oxidative enzymes, which, although equally important in soil dynamics, are less well studied. In order to obtain a general picture of soil quality, we therefore need to investigate the activity not only of hydrolytic enzymes but also of oxidative enzymes.

One of the main, and most studied, groups of enzymes involved in oxidative processes is phenol oxidases (POs) (Stursova and Sinsabaugh, 2008), which are extracellular oxidoreductase enzymes. They are released into the environment through excretion or cellular lysis. Once in the soil, they can oxidize phenolic compounds and degrade lignin and humic substances, permitting the release of $\mathrm{C}$ and other nutrients (Piotrowska-Dlugosz 2014; Sinsabaugh 2010). Previous studies demonstrated that POs apparently behave differently from hydrolytic enzymes, and therefore, their activities are often not correlated (Stursova and Sinsabaugh, 2008). For example, it has been observed that, in contrast to PO activities, hydrolytic activities tend to decrease with increasing soil depth (Jackson et al. 2009). In addition, activities such as carbohydrate hydrolysis increase after $\mathrm{N}$ fertilization, whereas oxidative enzyme activities tend to decline (Moorhead and Sinsabaugh 2006). This suggests that PO activities are controlled by factors different from those controlling hydrolytic activities, and some soil processes seem to be mediated mostly by oxidative enzymes. For instance, Carreiro et al. (2000) have observed that in ecosystems where litter is low in lignin and $\mathrm{N}$ content (i.e. grasslands), enrichment with $\mathrm{N}$ increases the rate of organic matter decomposition, whereas the rate decreases in litter with high lignin content (i.e. temperate and boreal forests). The rate of decomposition was correlated with PO activity; the correlation was positive in correspondence to higher organic matter decomposition rate, whereas it was negative with lower organic matter decomposition rate (Allison and Vitousek 2004; Carreiro et al. 2000). Schimel and Weintraub (2003) studied a $\mathrm{N}$-limited model in which adding inorganic $\mathrm{N}$ produced a reduction in the microbial respiration rate (determined with the metabolic quotient, $\mathrm{qCO}_{2}$ ); this may be connected to the inhibition of ligninolytic enzymes that allow formation of more recalcitrant humic complexes.

Correlations between PO activities and hydrolytic enzyme activities, soil depth, and $\mathrm{N}$ application have been studied in ecosystems such as grasslands and forests. However, they are yet to be investigated in detail in agricultural systems where soil fertility is an important factor and organic matter content depends on agronomic management practices, such as fertilization, grassing, and crop rotation. We investigated the relationships between soil PO activities and the long-term effect of organic (compost) and mineral fertilization in an experimental walnut orchard. Fertilization practices can indeed have a great impact on soil fertility, not only through nutrient inputs entering soil, but also through organic matter decomposition rates (Giacometti et al. 2013). For example, both organic and inorganic $\mathrm{N}$ inputs induce a reduction in the degradation of recalcitrant $\mathrm{C}$ related to decreases in enzymes (such as $\mathrm{PO}$ ) responsible for its decomposition (Craine et al. 2007).

In this context, we assessed changes in soil PO activities in an agricultural system, taking into account the effects of $\mathrm{N}$ application. Based on the results of previous studies in natural ecosystems (Allison and Vitousek 2004; Carreiro et al. 2000; Jackson et al. 2009; Stursova and Sinsabaugh 2008), we expect to see differences between PO and hydrolytic microbial activities. In addition, we expected a reduction in PO activities as a consequence of $\mathrm{N}$ application that would bring greater sta- bilization of soil organic carbon estimated, for example, with the $\delta^{13} \mathrm{C}$ measure (Balesdent and Mariotti 1996; Ladyman and Harkness 1980).

The goal of this study was, therefore, to evaluate: (i) whether trends in $\mathrm{PO}$ activities differed from those in microbial biomass and activity, and in particular, from those in hydrolytic enzymatic activities; and (ii) whether fertilization management influenced $\mathrm{PO}$ activities, and whether organic or mineral $\mathrm{N}$ fertilizer input enhanced or reduced $\mathrm{PO}$ activities.

\section{Materials and methods}

\subsection{Study site and experimental design}

The experimental site belongs to the University of Bologna and is located in Cadriano (BO) in the southern Italian Po Valley $\left(45.53^{\circ} \mathrm{N}\right.$, $11.38^{\circ} \mathrm{E}, 28 \mathrm{~m}$ above sea level), which is an area characterized by high SOC depletion as a consequence of intensive agricultural exploitation (Malucelli et al. 2014). The experimental system was also chosen to enable a trial lasting for 14 years, a sufficiently long period to have a consolidated agrosystem where responses are not the result of temporary perturbations. Mean annual precipitation and temperature for the area are $747 \mathrm{~mm}$ and $14.2{ }^{\circ} \mathrm{C}$ respectively. A walnut (Juglans regia L.) orchard, consisting of the cultivar 'Lara' grafted on to seedling rootstock, was established in 2001 in a $7 \mathrm{~m} \times 8 \mathrm{~m}\left(179\right.$ trees ha $\left.^{-1}\right)$ grid on soil classified as fine-silty, mixed, superactive, mesic Udifluventic Haplustepts (USDA Soil Taxonomy), characterized by a basic sequence of horizons (Oi, A, Ag, Bg) and formed on alluvial sediment. The soil was initially characterized as sub-acid $\mathrm{pH}$ (6.8), with low content of active lime $\left(<30 \mathrm{~g} \mathrm{~kg}^{-1}\right)$, organic matter $\left(11 \mathrm{~g} \mathrm{~kg}^{-1}\right)$, and total $\mathrm{N}\left(1 \mathrm{~g} \mathrm{~g}^{-1}\right)$, whereas the soil $\mathrm{C} / \mathrm{N}$ ratio was 6.4 .

The climate of the area is classified as temperate sub-continental with cold winters and humid and warm summers. From the second growing season onwards, the orchard floor was not tilled, and maintained permanently with a mix of grass species (Lolium perenne L., Festuca rubra L., and Poa pratensis L.) mown twice a year. Trees, managed in terms of pruning, irrigation, and pest and disease control according to the regional guidelines for integrated crop management, were planted out in five rows, each with 20 plants, for a total field length of $135 \mathrm{~m}$ and a width of $40 \mathrm{~m}$.

From the time of planting, the orchard was divided into plots, each subjected to one of three different fertilizer treatments: i) unfertilized control; ii) with organic amendments; and iii) with mineral inputs. Organic and miner treatments received $\mathrm{N}$ at a rate of $100 \mathrm{~kg} \mathrm{ha}^{-1}$ year $^{-1}$, applied to the soil surface without tilling, while unfertilized control plots did not receive any external input. The organic N source was compost produced from a mix of organic municipal wastes, pruning material from urban ornamental trees and gardens, and agro-industrial organic residues, following a 3-month biological stabilization period under aerobic conditions (Table 1). Compost analysis revealed low presence of heavy metal $(\mathrm{Cr}(\mathrm{VI}), \mathrm{Pb}, \mathrm{Cu}, \mathrm{Cd}, \mathrm{Ni}, \mathrm{Zn}$, and $\mathrm{Hg}$ ) concentrations (Table 1). Compost was spread during the flowering period with rates of application adjusted annually. Commercial urea $(46 \% \mathrm{~N})$ was the $\mathrm{N}$ source applied to the mineral treatment plots, with total $\mathrm{N}$ rate split yearly between the flowering $(60 \%)$ and postharvest $(40 \%)$ periods. The treatments were compared using a randomized block design with five replicates, arranged in five adjacent rows of trees. Experimental units (replicates), each consisting of four consecutive trees, were randomly distributed within each row.

\subsection{Soil sampling and storage}

In May 2015, soil samples from the top $40 \mathrm{~cm}$ soil profile were collected from the middle of each replicate equidistant from the nearest trunks and inside the leaf canopy (one sample from every experimental 
Table 1

- Main chemical characteristics of compost used in the trail. Data are reported as means \pm SEM because every furniture of compost was analysed.

\begin{tabular}{ll}
\hline Parameters & Compost \\
\hline $\mathrm{pH}$ & $7.92 \pm 0.39$ \\
Moisture $(\% \mathrm{fm})$ & $40.6 \pm 2.41$ \\
Total nitrogen $\% \mathrm{dm})$ & $2.25 \pm 0.22$ \\
Total carbon $(\% \mathrm{dm})$ & $30.1 \pm 2.20$ \\
$\mathrm{C} / \mathrm{N} \mathrm{ratio}$ & $12.3 \pm 1.06$ \\
Total P $\left(\% \mathrm{P}_{2} \mathrm{O}_{5} \mathrm{dm}\right)$ & $0.5 \pm 0.1$ \\
Total $\mathrm{K}\left(\% \mathrm{~K}_{2} \mathrm{O} \mathrm{dm}\right)$ & $1.4 \pm 0.2$ \\
Total $\mathrm{Cr}\left(\mathrm{VI}\left(\mathrm{mg} \mathrm{kg}^{-1} \mathrm{dm}\right)\right.$ & $0.185 \pm 0.106$ \\
Total $\mathrm{Pb}\left(\mathrm{mg} \mathrm{kg}^{-1} \mathrm{dm}\right)$ & $33.4 \pm 5.59$ \\
Total $\mathrm{Cu}\left(\mathrm{mg} \mathrm{kg}^{-1} \mathrm{dm}\right)$ & $65.5 \pm 8.43$ \\
Total Cd $\left(\mathrm{mg} \mathrm{kg}^{-1} \mathrm{dm}\right)$ & $0.463 \pm 0.090$ \\
Total Ni $\left(\mathrm{mg} \mathrm{kg}^{-1} \mathrm{dm}\right)$ & $18.2 \pm 1.99$ \\
Total $\mathrm{Zn}\left(\mathrm{mg} \mathrm{kg}^{-1} \mathrm{dm}\right)$ & $136 \pm 16.5$ \\
Total $\mathrm{Hg}\left(\mathrm{mg} \mathrm{kg}^{-1} \mathrm{dm}\right)$ & $0.301 \pm 0.128$ \\
\hline
\end{tabular}

unit up to a total of 15 soils samples). Rainfall during the 4-6 weeks preceding sampling was average and therefore, at the time of sampling, soils were relatively moist (15-20\% of fresh weight). Each sample was divided into two subsamples (each approximately $300 \mathrm{~g}$ ): the first was representative of the top $0-20 \mathrm{~cm}$ of the soil profile, and the second of the bottom $20-40 \mathrm{~cm}$. Fresh samples were kept in a cooler for transport to the laboratory where they were sieved to $2 \mathrm{~mm}$; roots and plant residues were carefully removed by forceps. Samples were then homogenized and divided into two aliquots: one was air-dried whereas the other was stored in plastic bags at $4{ }^{\circ} \mathrm{C}$.

\subsection{Soil chemical analysis}

Soil carbonate content was determined using a calcimeter (ISO 10693, 1995). Soil $\mathrm{pH}$ was measured both in ultrapure water and in $1 \mathrm{M}$ $\mathrm{KCl}$ (ISO 10390, 2005). Total C $\left(\mathrm{C}_{\text {tot }}\right)$ and total $\mathrm{N}\left(\mathrm{N}_{\text {tot }}\right)$ were analysed using an elemental analyser (CHNS-O Elemental Analyzer 1110, Thermo Scientific $\mathrm{GmbH}$, Dreieich, Deutcheland). Stable isotopes $\left({ }^{15} \mathrm{~N}\right.$ and $\left.{ }^{13} \mathrm{C}\right)$ were measured using an elemental analyser coupled with isotopic mass.

Manganese oxide $\left(\mathrm{Mn}_{\mathrm{ox}}\right)$ content was determined using the selective dissolution method described by Gambrell (1996). Mn content of a diluted solution was determined by ICP-AES.

\subsection{Soil microbial biomass and activity}

Soil microbial biomass $\mathrm{C}\left(\mathrm{C}_{\text {mic }}\right)$ and $\mathrm{N}\left(\mathrm{N}_{\text {mic }}\right)$ were determined using the chloroform-fumigation extraction method (Vance et al. 1987). Extracts were analysed with an elemental analyser (TOC-VWP with TN Unit, Shimadzu Corp., Kyoto, Japan). $\mathrm{C}_{\text {mic }}$ was calculated as the difference between organic $\mathrm{C}$ in the fumigated and organic $\mathrm{C}$ in the unfumigated soil extracts. The organic $\mathrm{C}$ content of the unfumigated extracts was used as an estimation of soil extractable $\mathrm{C}\left(\mathrm{C}_{\text {ext }}\right)$. Microbial biomass $\mathrm{N}\left(\mathrm{N}_{\text {mic }}\right)$ and soil extractable $\mathrm{N}\left(\mathrm{N}_{\text {ext }}\right)$ were similarly calculated.

Soil microbial activity (Schnurer and Rosswall 1982) was determined using fluorescein diacetate [3',6'-diacetyl fluorescein (FDA)] hydrolysis (Adam and Duncan 2001). Absorbance was measured spectrophotometrically at $490 \mathrm{~nm}$. Activity was expressed as $\mathrm{g}$ fluorescein $\mathrm{kg}_{\mathrm{ds}}{ }^{-1} \mathrm{~h}^{-1}$.

\subsection{Soil enzymatic activities}

Dehydrogenase activity (DHD) was measured according to von Mersi and Schinner (1991). Released $p$-nitrophenol (INTF) was measured at $464 \mathrm{~nm}$ and the activity was expressed as mg INTF $\mathrm{kg}_{\mathrm{ds}}{ }^{-1} \mathrm{~h}^{-1}$.
Phenol oxidase activities measured were laccase (EC 1.10.3.2) that catalyses the transfer of a single electron, tyrosinase (EC 1.14.18.1) that catalyses reactions in which a second hydroxyl group is inserted in the ortho position of a monophenol (Prosser et al. 2011), and catechol oxidase (EC 1.10.3.1) that catalyses $o$-diphenol oxidation to produce a quinone and water.

Catechol oxidase activity was assayed according to Perucci et al. (2000). Absorbance was measured at $525 \mathrm{~nm}$ with a molar extinction coefficient of $5000 \mathrm{~L} \mathrm{~mol}^{-1} \mathrm{~cm}^{-1}$. Activity was expressed as $\mu \mathrm{mol}$ catechol $g_{d s}{ }^{-1} h^{-1}$.

Tyrosinase activity was measured according to Sinsabaugh et al. (1999). Absorbance was measured at $475 \mathrm{~nm}$ with a molar extinction coefficient of $3700 \mathrm{~L} \mathrm{~mol}^{-1} \mathrm{~cm}^{-1}$. Activity was expressed as $\mu$ mol DOPA $\mathrm{g}_{\mathrm{ds}}{ }^{-1} \mathrm{~h}^{-1}$.

Laccase activity was determined according to Floch et al. (2007). The reaction product $\left(\mathrm{ABTS}^{+}\right)$was measured spectrophotometrically at $420 \mathrm{~nm}$ with a molar extinction coefficient of $18,460 \mathrm{~L} \mathrm{~mol}^{-1} \mathrm{~cm}^{-1}$. Activity was expressed as $\mu \mathrm{mol} \mathrm{ABTS}{ }^{+} \mathrm{g}_{\mathrm{ds}}{ }^{-1} \mathrm{~min}^{-1}$.

\subsection{Soil respiration rate and eco-physiological index}

Soil basal respiration rate was determined through controlled incubation with a static approach and measured with a photoacoustic detector (Brüel and Kjær Multi-gas Monitor Type 1302): $20 \mathrm{~g}$ of moist soil were pre-incubated at $20{ }^{\circ} \mathrm{C}$ in airtight glass jars, which were aired every day. $\mathrm{CO}_{2}$ content in the headspace was measured daily for a week. Before the measurements, the jars were left open for $30 \mathrm{~min}$ and incubated for approximately $3 \mathrm{~h}$.

The metabolic quotient $\left(\mathrm{qCO}_{2}\right)$ was calculated by dividing basal respiration by $\mathrm{C}_{\text {mic }}$. Other eco-physiological parameters calculated were the metabolic index (Masciandaro et al. 1998), which was determined by dividing dehydrogenase activity (DHD) by extractable $\mathrm{C}\left(\mathrm{C}_{\text {ext }}\right)$, and the microbial quotient $\left(\mathrm{q}_{\text {mic }}\right)$, which was obtained by dividing $\mathrm{C}_{\text {mic }}$ by total organic $\mathrm{C}\left(\mathrm{C}_{\text {org }}\right)$.

\subsection{Data analysis}

Data were analysed using a split-plot design, with treatments (three levels) as the main factor and sampling depths (two levels) as the sub-factor. The assumptions of the ANOVA were tested using the Bartlett's test for homogeneity of variances, and the Shapiro-Wilk test for normality of the data. The data were transformed, if necessary, using the Box-Cox procedure. For simplicity, tables and figures report the original untransformed data. In addition, possible outliers were identified using boxplots and the [outlier] function in the R package 'outliers'. Pairwise means comparisons were carried out using Fisher's Least Significant Difference (LSD) test at the significance level $P \leq 0.05$. Pearson's correlation coefficients ( $r$ ) were also calculated. All statistical analyses were performed using R (R Core Team 2016).

\section{Results}

Data analysis revealed a high number of outliers belonging mostly to the first sampled block (or the first row of the field). This may have been due to the convexity of the outer rows of trees in the field and to the presence of a different type of soil in that area. Therefore, this block was removed from the data set, leading to a sharp reduction in outliers. Statistical analysis was then carried out again on the reduced data set, and the reported data thus represent the average of four out of the five blocks sampled initially. 


\subsection{Soil chemical analysis}

Soil $\mathrm{pH}$ in water $\left(\mathrm{pH}_{\mathrm{H} 2 \mathrm{O}}\right)$ generally ranged from 6.40 (mineral treatment and unfertilized control) to 7.04 (compost amendment), with no significant differences between samples from 0 to $20 \mathrm{~cm}$ and $20-40 \mathrm{~cm}$ of soil depth. Soil $\mathrm{pH}$ obtained in $1 \mathrm{M} \mathrm{KCl}\left(\mathrm{pH}_{\mathrm{KCl}}\right)$ ranged from 4.80 to 5.63 (Table 2), with significantly higher values in the compost-treated plots, and, irrespective of fertilization treatment, in the upper $(0-20 \mathrm{~cm})$ soil layer (Table 2).

The total amount of soil carbonates (Table 2) was generally low (approximately $2 \mathrm{~g} \mathrm{~kg}_{\mathrm{ds}}{ }^{-1}$ ), and for this reason, $\mathrm{C}_{\text {tot }}$ was taken as total organic $\mathrm{C}\left(\mathrm{C}_{\text {org }}\right)$.

Compost amendment significantly increased soil $\mathrm{C}_{\text {org }}$ and soil $\mathrm{N}_{\text {tot }}$ (Fig. 1a, b) compared to the untreated control, whereas mineral fertilizer treatment showed intermediate values. $\mathrm{C}_{\text {org }}$ and $\mathrm{N}_{\text {tot }}$ were significantly higher (a 2.12- and 1.81-fold increase, respectively) in the top soil layer irrespective of fertilization treatment.

While isotopic composition was affected by soil depth, the effect induced by fertilization was negligible. Indeed, both $\delta^{13} \mathrm{C}$ and $\delta^{15} \mathrm{~N}$ were influenced by depth, with the highest values in the deeper soil samples (Table 2).

The Mn oxide content (Table 2) ranged from 360 to $440 \mathrm{mg} \mathrm{kg}^{-1}$, with higher values observed in the deeper soil layers in the mineral fertilization treatment.

\subsection{Soil microbial biomass and activity}

Both factors (fertilization and depth) affected the measured extractable $\mathrm{C}\left(\mathrm{C}_{\text {ext }}\right)$. The compost-amended plots showed higher $\mathrm{C}_{\text {ext }}$ (Fig. $1 c)$, whereas the values in the plots fertilized with urea were comparable to those observed in unfertilized control plots. $\mathrm{C}_{\mathrm{ext}}$ was higher in the upper layer where repeated application of compost led to significantly higher values than those measured in the plots fertilized with urea; we observed the same trend at $20-40 \mathrm{~cm}$ depth, but with lower values for $\mathrm{C}_{\text {ext }}$. Extractable $\mathrm{N}\left(\mathrm{N}_{\text {ext }}\right)$ tended to be higher in the compost treatment in the top layer of soil (Fig. 1d), whereas it was observed a slight increase in the mineral fertilizer treatment in the deeper soil layer.

Microbial biomass $\mathrm{C}$ and $\mathrm{N}$ content $\left(\mathrm{C}_{\mathrm{mic}}\right.$ and $\left.\mathrm{N}_{\text {mic }}\right)$ were not significantly influenced by the different fertilizer treatments. Nevertheless, data indicate significantly higher $\mathrm{C}_{\text {mic }}$ (Fig. 1e) and $\mathrm{N}_{\text {mic }}$ (Fig. 1f) content in the upper soil layer than in the lower.

Microbial activity (FDA) appeared to be influenced more by depth than by fertilizer treatment. There was a significant interaction between the two factors (Fig. 2), indicating that microbial activity was higher in the $0-20 \mathrm{~cm}$ layer of soil in the compost treatment.

\subsection{Soil enzymatic activities}

Dehydrogenase activity (DHD) was not influenced by fertilizer treatment, but was influenced by soil depth. As shown in Fig. 3a, there was a clear difference in DHD activity between the upper and lower soil layers, with the highest values being recorded in the former. The highest values were observed at $0-20 \mathrm{~cm}$ depth in compost-treated plots where activity increased by $39 \%$ compared to urea-treated plots and by $69 \%$ compared to unfertilized control plots. Catechol oxidase (Fig. 3b) and tyrosinase (Fig. 3c) activities were significantly affected by compost treatment in the surface layer. Tyrosinase activity (Fig. 3c) also showed significant differences between soil depths, reaching the highest values in the top 0-20 cm layer.

We did not observe any significant effects in laccase activity attributable to fertilizer treatment, although higher values were generally detected in the deeper soil layer (Fig. 3d). Interaction between factors highlights an increase in activity in the compost treatment relative to the control, whereas the increase in activity was greater in the deeper soil layer in the mineral fertilizer treatment (Fig. 3d).

\subsection{Soil basal respiration rate and eco-physiological index}

Fertilizer treatment did not influence soil basal respiration rate (SBR) (Table 2), whereas soil depth affected metabolic quotient $\left(\mathrm{qCO}_{2}\right)$, with higher values within the $20-40 \mathrm{~cm}$ layer. Metabolic index (DHD/ $\mathrm{C}_{\mathrm{ext}}$ ) and microbial quotient (qmic) were affected only by sampling depth, with a tendency to decrease with increasing depth (Table 2).

\subsection{Specific soil enzymatic activities}

Specific soil enzymatic activity can be considered a simple index of soil quality (Gil-Sotres et al. 2005; Kandeler and Eder 1993; Trasar-Cepeda et al. 2008), and was calculated by comparing PO activity values with microbial biomass $C$ content $\left(C_{\text {mic }}\right)$. The ratio was also calculated with organic $\mathrm{C}$ content $\left(\mathrm{C}_{\text {org }}\right)$, but data are not reported as the results were the same as those obtained with $\mathrm{C}_{\text {mic }}$.

Specific dehydrogenase activity did not show significant differences between fertilizer treatments or sampling depths (Fig. 4a). In the case of specific phenol oxidase activity, the observed differences were only between sampling depths (Fig. 4b, c, d). However, Fig. 4 shows that activity was lower in the compost treatment, although the differences are not statistically significant.

Table 2

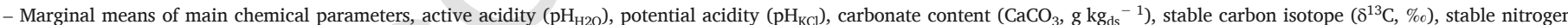

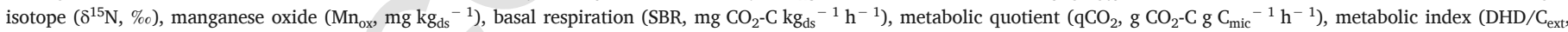

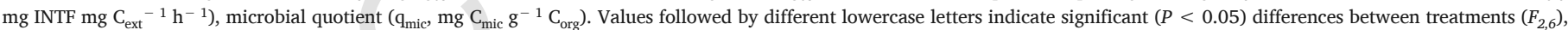
sampling depth $\left(F_{1,9}\right)$ or interaction treatments vs. sampling depth $\left(F_{2,9}\right)$ as determined by LSD Fischer's test.

\begin{tabular}{|c|c|c|c|c|c|c|c|c|c|c|}
\hline & $\mathrm{pH}_{\mathrm{H} 2 \mathrm{O}}$ & $\mathrm{pH}_{\mathrm{KCl}}$ & $\mathrm{CaCO}_{3}$ & $\delta^{13} \mathrm{C}$ & $\delta^{15} \mathrm{~N}$ & $\mathrm{Mn}_{\mathrm{OX}}$ & SBR & $\mathrm{qCO}_{2}$ & $\mathrm{DHD} / \mathrm{C}_{\mathrm{ext}}$ & $\mathrm{q}_{\text {mic }}$ \\
\hline \multicolumn{11}{|l|}{ Treatments } \\
\hline Organic & $7.04^{\mathrm{a}}$ & $5.63^{\mathrm{a}}$ & $2.35^{\mathrm{a}}$ & $-26,6$ & 6.83 & $374^{\mathrm{b}}$ & 4.51 & 5.45 & 0.51 & 8.37 \\
\hline Mineral & $6.40^{\mathrm{b}}$ & $4.88^{\mathrm{b}}$ & $1.97^{\mathrm{b}}$ & $-26,2$ & 7.03 & $403^{\mathrm{a}}$ & 4.12 & 6.35 & 0.56 & 7.96 \\
\hline Control & $6.44^{\mathrm{b}}$ & $4.80^{\mathrm{b}}$ & $1.88^{\mathrm{b}}$ & $-26,1$ & 6.60 & $375^{\mathrm{b}}$ & 3.94 & 6.43 & 0.57 & 7.86 \\
\hline$P$-value & 0.021 & 0.018 & 0.010 & 0.108 & 0.185 & 0.025 & 0.399 & 0.671 & 0.851 & 0.764 \\
\hline \multicolumn{11}{|l|}{ Sampling depth } \\
\hline $1(0-20 \mathrm{~cm})$ & 6.60 & $5.27^{\mathrm{a}}$ & 2.15 & $-26,8^{b}$ & $6.21^{\mathrm{b}}$ & $362^{\mathrm{b}}$ & 4.08 & $3.23^{\mathrm{b}}$ & $0.68^{\mathrm{a}}$ & $8.78^{\mathrm{a}}$ \\
\hline $2(20-40 \mathrm{~cm})$ & 6.65 & $4.93^{\mathrm{b}}$ & 1.98 & $-25,8^{a}$ & $7.44^{\mathrm{a}}$ & $406^{\mathrm{a}}$ & 4.30 & $8.92^{\mathrm{a}}$ & $0.41^{\mathrm{b}}$ & $7.35^{\mathrm{b}}$ \\
\hline$P$-value & 0.633 & 0.006 & 0.226 & $\leq 0.001$ & $\leq 0.001$ & 0.036 & 0.616 & $\leq 0.001$ & 0.017 & 0.005 \\
\hline \multicolumn{11}{|c|}{ Treatments x depth } \\
\hline$P$-value & 0.103 & 0.037 & 0.383 & 0.348 & 0.172 & 0.482 & 0.435 & 0.898 & 0.947 & 0.376 \\
\hline
\end{tabular}



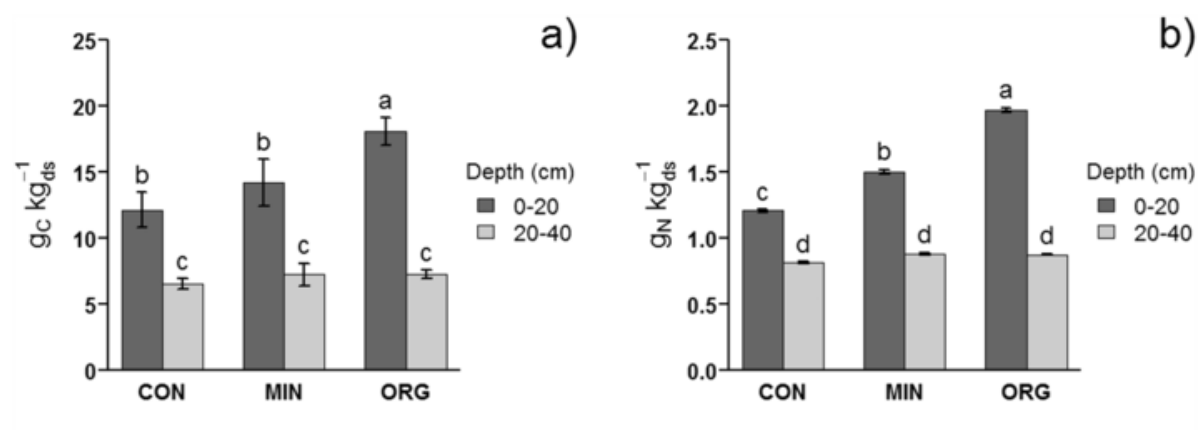

b)
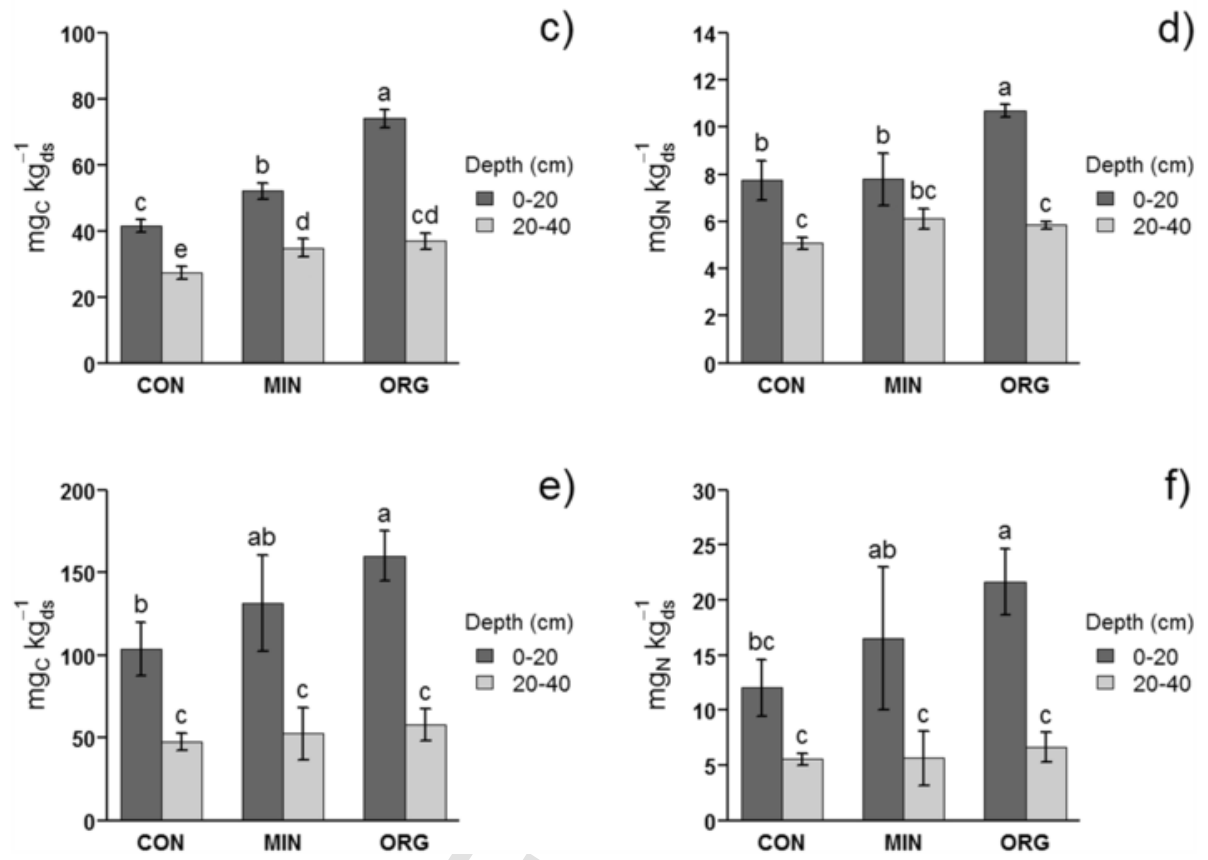

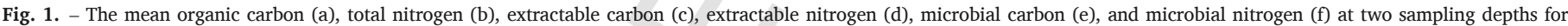

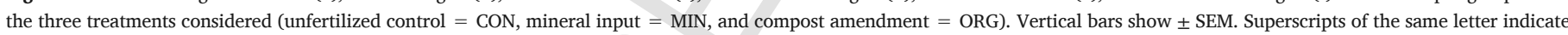
means that are not significantly different when compared with LSD Fischer's test.

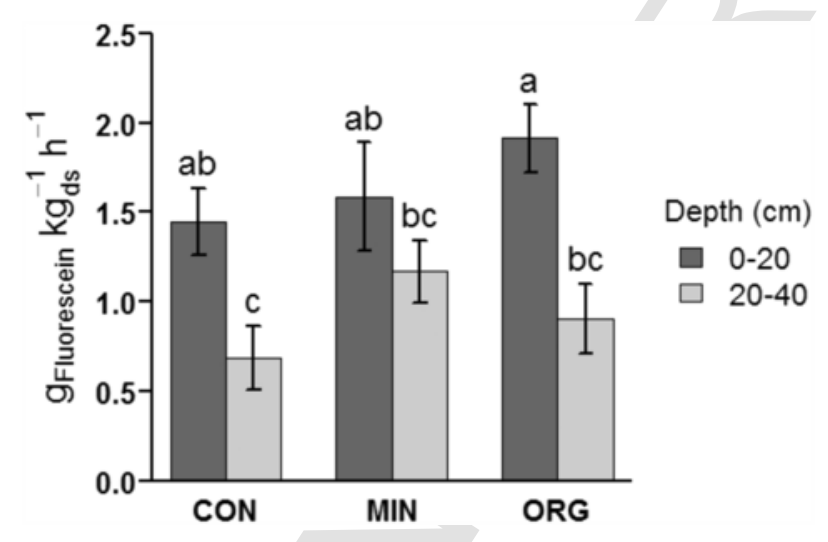

Fig. 2. - The mean microbial activity at two sampling depths for the three treatments considered (unfertilized control $=\mathrm{CON}$, mineral input $=$ MIN, and compost amendment $=$ ORG). Vertical bars show \pm SEM. Superscripts of the same letter indicate means that are not significantly different when compared with LSD Fischer's test.

\section{Discussion}

Application of $\mathrm{N}$ to the orchard, either from organic or from mineral sources, considerably influenced soil microbial biomass and activity as well as soil $\mathrm{C}$ and $\mathrm{N}$ pools (Fig. 1). Although these responses were expected, a previous study confirmed that, in the absence of external fertilization, pedoclimatic conditions (in our site), no tillage, and a stable grassland were not enough for obtaining a substantial stock of organic matter in the upper $(0-20 \mathrm{~cm})$ soil layer (Cattaneo et al. 2014). On the other hand, repeated application of compost to the soil increased these pools significantly (Giacometti et al. 2013). After 14 years of treatment, $\mathrm{C}_{\text {ext }}$ (the dynamic C pool) increased by $61 \%, \mathrm{C}_{\text {mic }}$ by $44 \%, \mathrm{~N}_{\text {ext }}$ by $29 \%, \mathrm{~N}_{\text {mic }}$ by $61 \%, \mathrm{C}_{\text {org }}$ by $36 \%$, and TN by $20 \%$ compared to the unfertilized control (Fig. 1). These results were expected as similar studies conducted in the same region led to $\mathrm{C}_{\text {org }}$ increases ranging from $24 \%$ to $50 \%$, TN increases from $14 \%$ to $42 \%$, and microbial C and $\mathrm{N}$ pool increases by approximately $40 \%$ depending on the duration of experiments (Giacometti et al. 2013; Triberti et al. 2008).

Given the wide extent of research to date on variation in hydrolase enzyme activity after $\mathrm{C}$ or $\mathrm{N}$ fertilization, we measured only FDA hydrolysis rather than single hydrolytic enzyme activity, as the former is considered a general indicator of hydrolytic microbial activity. In the correlation matrix (Table 3), soil FDA and DHD were both positively correlated with organic and microbial $\mathrm{C}$, and with total and microbial N. Nevertheless, the effect of fertilization treatment on hydrolytic microbial activity, such as FDA, was less pronounced (an increase by only $32 \%$ and $29 \%$ induced by compost or urea, respectively) than the effects of sampling depth (Fig. 2). As seen in previous studies 

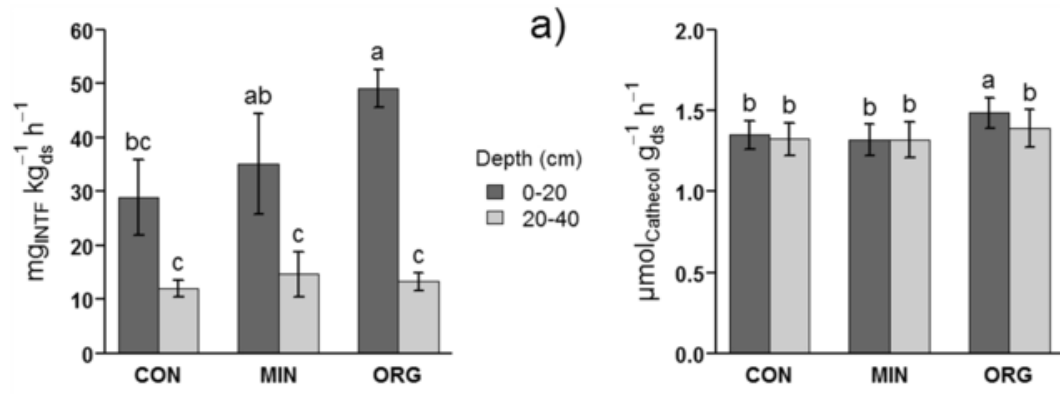

b)
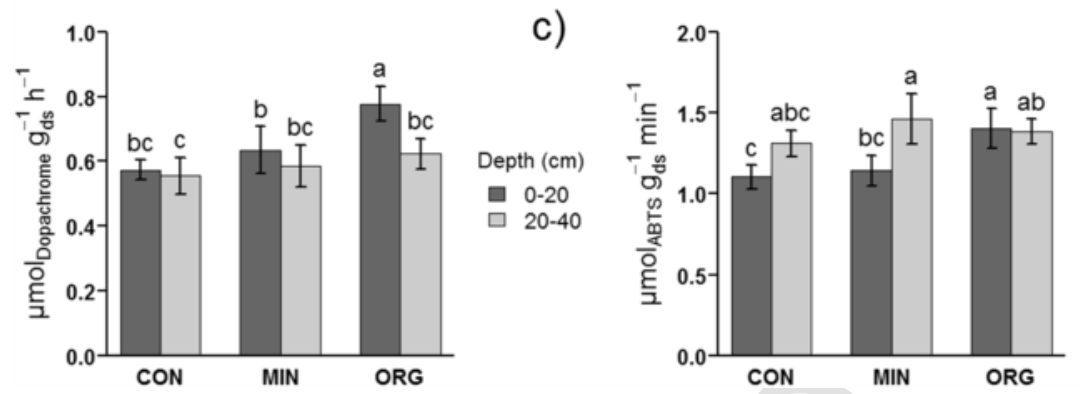

d)

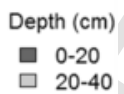

Depth $(\mathrm{cm})$

0-20

- 20-40

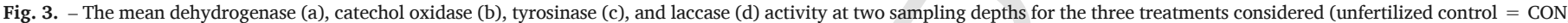

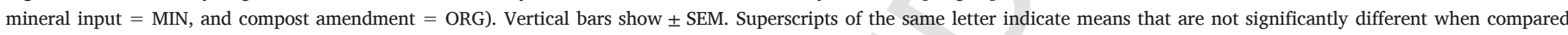
with LSD Fischer's test.
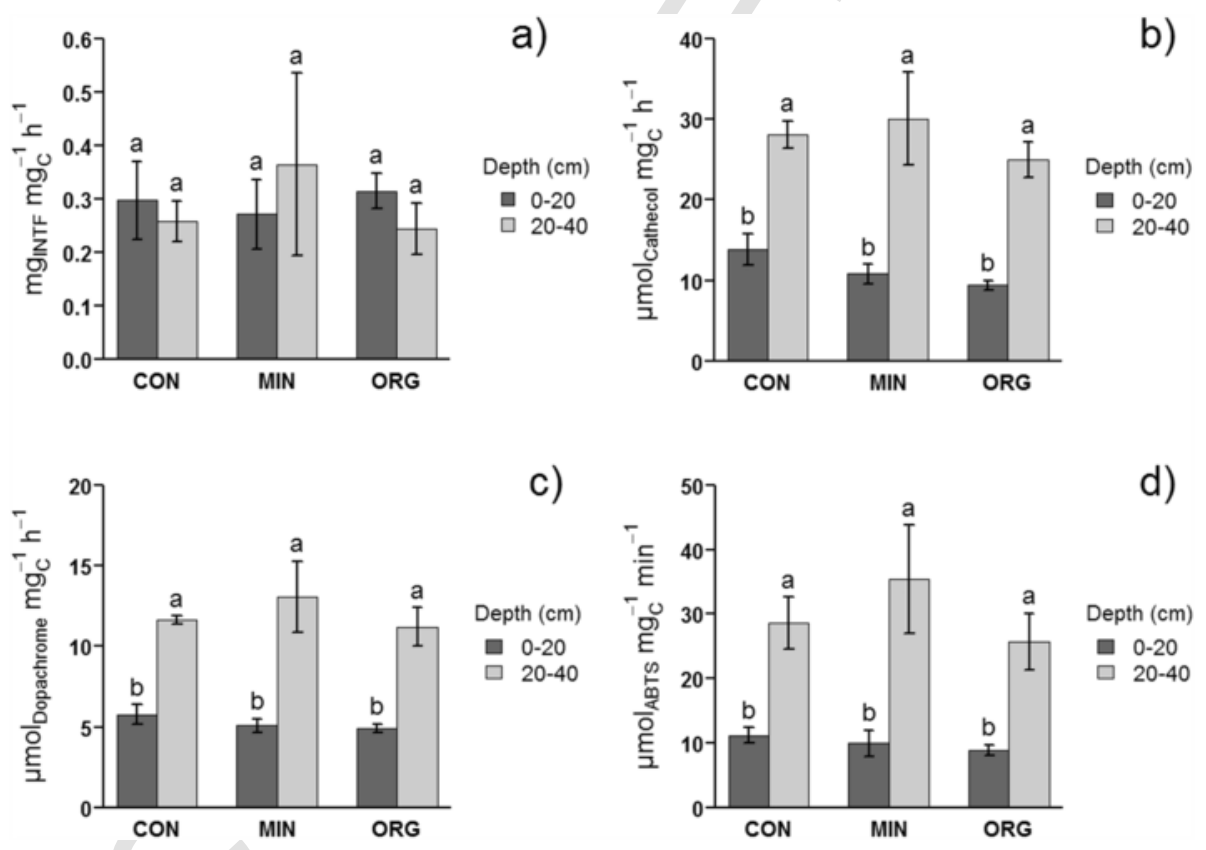

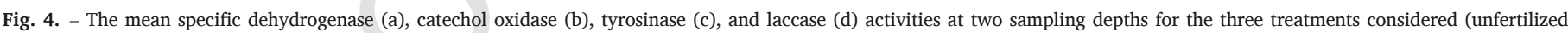

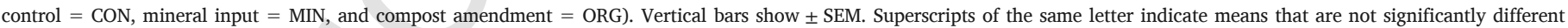
when compared with LSD Fischer's test.

(Mangalassery et al. 2015), in the soil sub-surface layer, there is a general decrease in FDA (by 44\%) and DHD (by 65\%) activity that may be ascribed to a limitation in $\mathrm{C}$ and/or $\mathrm{N}$ availability in this layer. This appears to be confirmed by the fact that $\mathrm{qCO}_{2}$ and $\mathrm{DHD} / \mathrm{C}_{\mathrm{ext}}$, two indices of microorganism substrate use efficiency, showed an opposite trend along the soil profile (Table 2), implying that the available $\mathrm{C}$ present at $20-40 \mathrm{~cm}$ depth was used more for respiration than for $\mathrm{C}$ assimilation and that microbial metabolism was less efficient (Masciandaro et al. 1998). This is further confirmed by the fact that DHD activity showed a negative correlation with the $\mathrm{qCO}_{2}$ index (Table 3), which, in addition to being an index of stress, is a measure of the degree of substrate limitation and of microbial biomass efficiency in utilizing $\mathrm{C}$ resources (Wardle and Ghani 1995). Differences in $\mathrm{qCO}_{2}$ were linked only to sampling depth (Table 2), indicating therefore that the biota within the $20-40 \mathrm{~cm}$ soil depth was more stressed, or mainly composed of microorganisms with low efficiency in substrate utilization (i.e. bacteria), or indicating lower $\mathrm{C}$ and $\mathrm{N}$ availability.

Isotopic $\delta^{13} \mathrm{C}$ measurements provide information about soil $\mathrm{C}$ turnover and SOM dynamics (Cattaneo et al. 2014). Data showed enrichment of ${ }^{13} \mathrm{C}$ content (i.e. $\delta^{13} \mathrm{C}$ values were less negative) in the 
Table 3

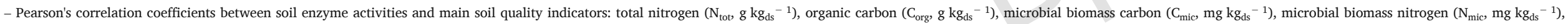

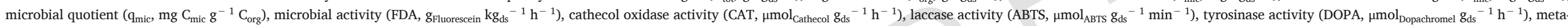

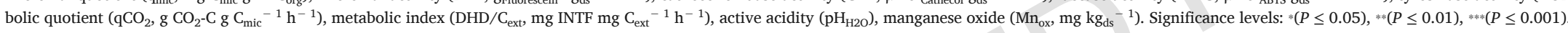

\begin{tabular}{|c|c|c|c|c|c|c|c|c|c|c|c|c|c|}
\hline & $\mathrm{N}_{\text {tot }}$ & $\mathrm{C}_{\text {org }}$ & $\mathrm{C}_{\text {mic }}$ & $\mathrm{N}_{\text {mic }}$ & $\mathrm{q}_{\text {mic }}$ & FDA & CAT & ABTS & DOPA & DHD & $\mathrm{qCO}_{2}$ & $\mathrm{DHD} / \mathrm{C}_{\mathrm{ext}}$ & $\mathrm{pH}_{\mathrm{H} 2 \mathrm{O}}$ \\
\hline $\mathrm{N}_{\text {tot }}$ & 1 & & & & & & & & & & & & \\
\hline $\mathrm{C}_{\text {org }}$ & $0.98^{* * * *}$ & 1 & & & & & & & & & & & \\
\hline $\mathrm{C}_{\mathrm{mic}}$ & $0.96^{* * * *}$ & $0.97 * * *$ & 1 & & & & & & & & & & \\
\hline $\mathrm{N}_{\text {mic }}$ & $0.92^{* * * *}$ & $0.92^{* * *}$ & $0.97^{* * *}$ & 1 & & & & & & & & & \\
\hline $\mathrm{q}_{\text {mic }}$ & $0.60^{* *}$ & $0.61^{* *}$ & $0.76^{* * * *}$ & $0.74^{* * * *}$ & 1 & & & & & & & & \\
\hline FDA & $0.75^{* * *}$ & $0.78^{* * *}$ & $0.71^{* * *}$ & $0.70^{* * * *}$ & 0.29 & 1 & & & & & & & \\
\hline СAT & $0.49 *$ & $0.42^{*}$ & $0.55^{* *}$ & $0.59^{* * *}$ & $0.75^{* * * *}$ & 0.29 & 1 & & & & & & \\
\hline ABTS & -0.09 & -0.18 & -0.18 & -0.16 & -0.17 & -0.11 & 0.15 & 1 & & & & & \\
\hline DOPA & $0.77^{* * *}$ & $0.70^{* * *}$ & $0.78^{* * *}$ & $0.83^{* * * *}$ & $0.75^{* * *}$ & $0.52^{* *}$ & $0.84 * * *$ & 0.08 & 1 & & & & \\
\hline DHD & $0.84 * * *$ & $0.86^{* * *}$ & $0.79^{* * * *}$ & $0.74 * * *$ & 0.38 & $0.72^{* * *}$ & 0.21 & -0.18 & $0.50^{* * *}$ & 1 & & & \\
\hline $\mathrm{qCO}_{2}$ & $-0.70^{* * *}$ & $-0.75^{* * *}$ & $-0.76^{* * * *}$ & $-0.66^{* * *}$ & $-0.72^{* * *}$ & $-0.42^{*}$ & $-0.41^{*}$ & 0.17 & $-0.52^{* *}$ & $-0.51^{* *}$ & 1 & & \\
\hline $\mathrm{DHD} / \mathrm{C}_{\mathrm{ext}}$ & $0.53^{* *}$ & $0.58^{* *}$ & $0.55^{* *}$ & $0.51 * *$ & 0.33 & $0.50^{* * *}$ & 0.15 & -0.17 & 0.29 & $0.84 * * *$ & -0.34 & 1 & \\
\hline $\mathrm{pH}_{\mathrm{H} 2 \mathrm{O}}$ & $0.42^{*}$ & 0.34 & $0.45^{*}$ & $0.51 *$ & $0.62^{* *}$ & 0.18 & $0.84 * * *$ & 0.10 & $0.83^{* * *}$ & 0.15 & -0.32 & -0.02 & 1 \\
\hline $\mathrm{Mn}_{\mathrm{ox}}$ & -0.13 & -0.22 & -0.13 & -0.04 & 0.07 & -0.01 & $0.44^{*}$ & 0.14 & 0.26 & -0.25 & 0.22 & -0.12 & $0.40^{*}$ \\
\hline
\end{tabular}


deeper layer (an increase by 4\%), meaning that the most transformed organic matter is located at $20-40 \mathrm{~cm}$ depth (Ladyman and Harkness 1980). The $\delta^{13} \mathrm{C}$ value is also an expression of increasing age of organic $\mathrm{C}$ and its degree of degradation, and an increase in $\delta^{13} \mathrm{C}$ with depth may be due to isotope fractionation during decay (Balesdent and Mariotti 1996; O'brien and Stout 1978). Therefore, comparison of $\delta^{13} \mathrm{C}$ values with $\mathrm{qCO}_{2}$ and $\mathrm{DHD} / \mathrm{C}_{\text {ext }}$ values implies that available $\mathrm{C}$ is low at $20-40 \mathrm{~cm}$ depth and that microorganisms, not being efficient enough, are not able to use the more recalcitrant forms of C.

Fertilization significantly affected all PO activities (Fig. 3), with significant increases in the soil surface layer of the compost treatment, compared to the control and mineral fertilization treatments. Although mineral $\mathrm{N}$ fertilization, compared to the untreated control, did not lead to variation in catechol oxidase activity, it led to an increase in tyrosinase activity, which was highest at $0-20 \mathrm{~cm}$ depth, and a significant increase in laccase activity at $20-40 \mathrm{~cm}$ depth. Several studies reported that enrichment with mineral $\mathrm{N}$ in grasslands, where microbial communities are dominated by Glomeromycota and Ascomycota (Porras-Alfaro et al. 2011), did not lead to reductions in PO activity (Zeglin et al. 2007) or a substantial increase in soil organic matter. On the other hand, in temperate forests where saprophytic Basidiomycetes constitute a predominant part of the microbial community and synthesize phenol oxidase, protease, and chitinase enzymes, addition of mineral $\mathrm{N}$ caused a reduction in oxidative enzyme activities (Zeglin et al. 2007). In our experimental site, the mineral $\mathrm{N}$ treatment affected $\mathrm{PO}$ expression and activity in different ways. It is noteworthy that the increase in tyrosinase and laccase activity is a trend opposite to that observed in other studies (Craine et al. 2007; Moorhead and Sinsabaugh 2006; Schimel and Weintraub 2003; Zeglin et al. 2007).

Moreover, tyrosinase and laccase enzymatic activities were significantly correlated with sampling depth. While tyrosinase activity decreased with depth, laccase activity increased. This different behaviour over space may be explained if we consider, in addition to the $\mathrm{qCO}_{2}$ data, fertilization effects on $\mathrm{C}_{\text {ext }}$ and $\mathrm{N}_{\text {ext }}$ concentration across soil depths. At $20-40 \mathrm{~cm}$ depth, mineral fertilization led to an increase in $\mathrm{N}_{\text {ext }}$ concentration, whereas compost seemed to favour $\mathrm{C}_{\text {ext }}$ content. This implies that increases in $\mathrm{N}_{\text {ext }}$ concentration stimulate laccases to recover $\mathrm{C}$ from more recalcitrant compounds (i.e. humic substances), whereas increases in $\mathrm{C}_{\text {ext }}$ concentration lead to lower expression of laccase activity. However, it should be highlighted that laccase activity and extractable $\mathrm{C}$ and $\mathrm{N}$ are not correlated.

Bach et al. (2013) showed that the ability of phenol oxidase to oxidize a particular substrate (i.e. humic substances) is related to the redox potential difference between the first active site in the reaction chain and the substrate and to soil $\mathrm{pH}$. In general, to break these types of bonds, it is necessary to have a high redox potential (i.e. $>1000 \mathrm{mV}$ ), higher than those of phenol oxidases (Bach et al. 2013) such as tyrosinases. Redox potentials can be reached with the aid of redox mediators (i.e. organic radicals) produced by laccases (Bach et al. 2013). Correlation results (Table 3 ) seem to support this hypothesis, as PO activities measured using catechol and L-DOPA as substrates were indeed positively correlated with $\mathrm{C}$ content, $\mathrm{N}$ content, $\mathrm{pH}$, and the microbial quotient $\left(\mathrm{q}_{\text {mic }}\right)$, whereas laccase activity was not correlated with these parameters. Moreover, laccase activity had a positive (although not significant) correlation with $\mathrm{qCO}_{2}$ whereas other activities, both hydrolytic and oxidative, were significantly negatively correlated with this parameter. Therefore, as observed by Nannipieri et al. (2002), there is a need to use different enzymatic activities to evaluate soil quality and fertility.

The correlation matrix (Table 3 ) also highlights a positive relationship between $\mathrm{Mn}_{\mathrm{ox}}$ content, and soil $\mathrm{pH}$ (Kampf et al. 2011) and a negative relationship between $\mathrm{Mn}_{\mathrm{ox}}$ content and catechol oxidase activity (Table 3). Although not correlated with $\mathrm{Mn}_{\mathrm{ox}}$ content, we found that tyrosinase and laccase behaved in a similar way to catechol oxidase rela- tion to $\mathrm{Mn}_{\mathrm{ox}}$ content (Table 1). Baldrian (2006) demonstrated that laccases catalyse $\mathrm{Mn}^{2}+$ oxidation in the presence of chelating agents, whereas Floch et al. (2009) observed that PO activities can be either stimulated or inhibited by the presence of metals (including Mn). It is therefore not surprising that, as already reported by Floch et al. (2009), the presence of $\mathrm{Mn}_{\mathrm{ox}}$ in soil may have influenced PO activities in different ways.

Specific PO activities (Fig. 4) were always higher in the sub-surface layer, with lower values observed in plots receiving compost. However, these results must be viewed with caution, as it is likely that the addition of compost led to a reduction in PO activities, especially that responsible for degradation of lignin. This interpretation may be supported by the laccase activity data (Fig. 3) which showed that while there was greater laccase activity at $20-40 \mathrm{~cm}$ depth in the untreated control and mineral $\mathrm{N}$ treatment plots, the reverse was the case in compost treatment plots where activity was higher at the $0-20 \mathrm{~cm}$ depth. However, the increase in phenol oxidases after compost addition is also consistent with their role in the removal of soluble phenolic compounds.

\section{Conclusion}

Compost application, compared to mineral $\mathrm{N}$ addition or no fertilizer enrichment, led to an improvement of the system with regard to both abiotic and biotic parameters. Soil depth was also a highly significant factor, especially in relation to enzyme activities. Using the classification proposed by Moorhead and Sinsabaugh (2006), the results obtained may be seen as suggesting that catechol oxidase and tyrosinase are produced by decomposers to degrade cellulose and lignocellulose, whereas laccase is produced by miners to degrade the more recalcitrant $\mathrm{C}$ pools with the aim of offsetting $\mathrm{C}_{\text {ext }}$ deficiency.

Therefore, PO activities, compared to the other soil functional indicators, did not show clear-cut behaviour and results are not easily generalizable. This means that soil functionality is the result of a wide range of different activities. Therefore, soil oxidase activities need to be investigated in greater depth, linking their variation to microbial composition, in order to understand the mechanisms regulating them.

\section{Acknowledgments}

We would like to thank Prof. Moreno Toselli of the Department of Agricultural Sciences of the University of Bologna for the management of the experimental trial. Thanks also to Dr. Patrizia Guidi for soil description and classification, Dr. Paola Gioacchini for performing the CHN-O and TOC-VCPH/CPN measurements and Dr. Andrea Simoni for performing the ICP-AES measurements.

\section{Funding sources}

This research did not receive any specific grant from funding agencies in the public, commercial, or not-for-profit sectors.

\section{References}

Adam, G., Duncan, H., 2001. Development of a sensitive and rapid method for the measurement of total microbial activity using fluorescein diacetate (FDA) in a range of soils. Soil Biol. Biochem. 33, 943-951. https://doi.org/10.1016/ S0038-0717(00)00244-3

Allison, S.D., Vitousek, P.M., 2004. Extracellular enzyme activities and carbon chemistry as drivers of tropical plant litter decomposition. Biotropica 36, 285-296.

Bach, C.E., Warnock, D.D., Van Horn, D.J., Weintraub, M.N., Sinsabaugh, R.L., Allison, S.D., German, D.P., 2013. Measuring phenol oxidase and peroxidase activities with pyrogallol, 1-DOPA, and ABTS: effect of assay conditions and soil type. Soil Biol. Biochem. 67, 183-191. https://doi.org/10.1016/j.soilbio.2013.08.022.

Baldrian, P., 2006. Fungal laccases-occurrence and properties. FEMS Microbiol. Rev. 30 , 215-242. https://doi.org/10.1111/j.1574-4976.2005.00010.x.

Balesdent, J., Mariotti, A., 1996. In: Boutton, T.W., Yamasaki, S. (Eds.), Measurement of Soil Organic Matter Turnover Using 13C Natural Abundance. Mass Spectrom. Soils. Marcel Dekker, New York, pp. 83-111. 
Carreiro, M.M., Sinsabaugh, R.L., Repert, D.A., Parkhurst, D.F., 2000. Microbial enzyme shifts explain litter decay responses to simulated nitrogen deposition. Ecology 81, 2359-2365. https://doi.org/10.1890/0012-9658(2000)081 [2359:MESELD]2.0.CO;2.

Cattaneo, F., Barbanti, L., Gioacchini, P., Ciavatta, C., Marzadori, C., 2014. C-13 abundance shows effective soil carbon sequestration in Miscanthus and giant reed compared to arable crops under Mediterranean climate. Biol. Fertil. Soils 50, 1121-1128. https://doi.org/10.1007/s00374-014-0931-x.

Core Team, R., 2016. R: a language and environment for statistical computing. In: R Foundation for Statistical Computing, Vienna, Austria, (URL https://www.R-project.org/).

Craine, J.M., Morrow, C., Fierer, N., 2007. Microbial nitrogen limitation increases decomposition. Ecology 88, 2105-2113. https://doi.org/10.1890/06-1847.1.

Finn, D., Page, K., Catton, K., Kienzle, M., Robertson, F., Armstrong, R., Dalal, R., 2016. Ecological stoichiometry controls the transformation and retention of plant-derived organic matter to humus in response to nitrogen fertilization. Soil Biol. Biochem. 99, 117-127. https://doi.org/10.1016/j.soilbio.2016.05.006.

Floch, C., Alarcon-Gutiérrez, E., Criquet, S., 2007. ABTS assay of phenol oxidase activity in soil. J. Microbiol. Methods 71, 319-324. https://doi.org/10.1016/j.mimet.2007.09. 020.

Floch, C., Alarcon-Gutiérrez, E., Criquet, S., 2009. Metal effects on phenol oxidase activities of soils. Ecotoxicol. Environ. Saf. 72, 108-114. https://doi.org/10.1016/j.ecoenv. 2008.03.008

Gambrell, R.P., 1996. Manganese. In: Sparks, D.L. (Ed.), Book Series 5 SSSA. Method of Soil Analysis Part 3 - Chemical Methods pp. 665-682.

Giacometti, C., Demyan, M.S., Cavani, L., Marzadori, C., Ciavatta, C., Kandeler, E., 2013. Chemical and microbiological soil quality indicators and their potential to differentiate fertilization regimes in temperate agroecosystems. Appl. Soil Ecol. 64, 32-48. https://doi.org/10.1016/j.apsoil.2012.10.002.

Giacometti, C., Cavani, L., Baldoni, G., Ciavatta, C., Marzadori, C., Kandeler, E., 2014. Microplate-scale fluorometric soil enzyme assays as tools to assess soil quality in a long-term agricultural field experiment. Appl. Soil Ecol. 75, 80-85. https://doi.org/ 10.1016/j.apsoil.2013.10.009.

Gil-Sotres, F., Trasar-Cepeda, C., Leirós, M.C., Seoane, S., 2005. Different approaches to evaluating soil quality using biochemical properties. Soil Biol. Biochem. 37, 877-887. https://doi.org/10.1016/j.soilbio.2004.10.003.

Jackson, C.R., Liew, K.C., Yule, C.M., 2009. Structural and functional changes with depth in microbial communities in a tropical Malaysian peat swamp forest. Microb. Ecol. 57, 402-412. https://doi.org/10.1007/s00248-008-9409-4.

Kampf, N., Scheinost, A.C., Schulze, D.G., 2011. Oxide minerals in soils. Handb. Soil Sci. Prop. Process. 1-34. https://doi.org/10.1201/b11267-26.

Kandeler, E., Eder, G., 1993. Effect of cattle slurry in grassland on microbial biomass and on activities of various enzymes. Biol. Fertil. Soils 16, 249-254. https://doi.org/10. 1007/BF00369300.

Ladyman, S.J., Harkness, D.D., 1980. Carbon isotope measurement as an index. Radiocarbon $22,885-891$.

Lal, R., 2004. Soil carbon sequestration impacts on global climate change and food security. Science 304, 1623-1627. https://doi.org/10.1126/science.1097396.

Malucelli, F., Certini, G., Scalenghe, R., 2014. Soil is brown gold in the Emilia-Romagna region, Italy. Land Use Policy 39, 350-357. https://doi.org/10.1016/j.landusepol.2014. 01.019.

Mangalassery, S., Mooney, S.J., Sparkes, D.L., Fraser, W.T., Sjögersten, S., 2015. Impacts of zero tillage on soil enzyme activities, microbial characteristics and organic matter functional chemistry in temperate soils. Eur. J. Soil Biol. 68, 9-17. https://doi.org/10. 1016/j.ejsobi.2015.03.001.

Masciandaro, G., Ceccanti, B., Gallardo-Lancho, J.F., 1998. Organic matter properties in cultivated versus set-aside arable soils. Agric. Ecosyst. Environ. 67, 267-274. https:// doi.org/10.1016/S0167-8809(97)00124-2.

von Mersi, W., Schinner, F., 1991. An improved and accurate method for determining the dehydrogenase activity of soils with iodonitrotetrazolium chloride. Biol. Fertil. Soils 11, 216-220. https://doi.org/10.1007/BF00335770.
Moorhead, Daryl L., Sinsabaugh, R.L., 2006. Mosaic patterns of thermal stress in the rocky intertidal zone: implications for climate change. Ecol. Monogr. 76, 151-174. https:// doi.org/10.1890/0012-9615(2006)076.

Nannipieri, P., Kandeler, E., Ruggiero, P., 2002. Enzyme activities and microbiological and biochemical processes in soil. In: Burns, R.G., Dick, R.P. (Eds.), Enzymes in the Environment: Activity, Ecology, and Applications. CRC Press, pp. 1-33.

Naseby, D.C., Lynch, J.M., 2002. Enzymes and microorganisms in the rhizosphere. In: Burns, R.G., Dick, R.P. (Eds.), Enzymes in the Environment: Activity, Ecology, and Applications. CRC Press, pp. 109-123. https://doi.org/10.1201/9780203904039.ch4.

O'brien, B.J., Stout, J.D., 1978. Movement and turnover of soil organic matter as indicated by carbon isotope measurements. Soil Biol. Biochem. 10, 309-317. https://doi.org/ 10.1016/0038-0717(78)90028-7.

Perucci, P., Casucci, C., Dumontet, S., 2000. An improved method to evaluate the o-diphenol oxidase activity of soil. Soil Biol. Biochem. 32, 1927-1933. https://doi.org/10. 1016/S0038-0717(00)00168-1.

Piotrowska-Dlugosz, A., 2014. Enzymes and soil fertility. In: Gianfreda, L., Rao, M. (Eds.), Enzymes in Agricultural Sciences. OMICS Group eBooks.

Porras-Alfaro, A., Herrera, J., Natvig, D.O., Lipinski, K., Sinsabaugh, R.L., 2011. Diversity and distribution of soil fungal communities in a semiarid grassland. Mycologia 103 10-21. https://doi.org/10.3852/09-297.

Prosser, J.A., Speir, T.W., Stott, D.E., 2011. Soil oxidoreductases and FDA hydrolysis. In: Dick, R.P. (Ed.), Methods of Soil Enzymology. Soil Science Society of America Inc., Madison, WI, pp. 103-124.

Rao, M., Scelza, R., Gianfreda, L., 2014. Soil enzymes. In: Gianfreda, L., Rao, M. (Eds.), Enzymes in Agricultural Sciences. OMICS Group eBooks.

Schimel, J.P., Weintraub, M.N., 2003. The implications of exoenzyme activity on microbial carbon and nitrogen limitation in soil: a theoretical model. Soil Biol. Biochem. 35, 549-563. https://doi.org/10.1016/S0038-0717(03)00015-4.

Schnurer, J., Rosswall, T., 1982. Fluorescein diacetate hydrolysis as a measure of total microbial activity in soil and litter. Appl. Environ. Microbiol. 43, 1256-1261, (doi:0099-2240/82/061256-06\$02.00/0).

Sinsabaugh, R.L., 2010. Phenol oxidase, peroxidase and organic matter dynamics of soil. Soil Biol. Biochem. 42, 391-404. https://doi.org/10.1016/j.soilbio.2009.10.014.

Sinsabaugh, R.L., Klug, M.J., Collins, H.P., Yeager, P.E., Peterson, S.O., 1999. Characterizing soil microbial communities. In: Robertson, G.P., Bledsoe, C.S., Coleman, D.C., Sollins, P. (Eds.), Standard Soil Methods for Long-Term Ecological Research. Oxford University Press, New York, pp. 318-348.

Spohn, M., 2015. Microbial respiration per unit microbial biomass depends on litter layer carbon-to-nitrogen ratio. Biogeosciences 12, 817-823. https://doi.org/10.5194/ bg-12-817-2015.

Stursova, M., Sinsabaugh, R.L., 2008. Stabilization of oxidative enzymes in desert soil may limit organic matter accumulation. Soil Biol. Biochem. 40, 550-553. https://doi.org/ 10.1016/j.soilbio.2007.09.002

Trasar-Cepeda, C., Leirós, M.C., Gil-Sotres, F., 2008. Hydrolytic enzyme activities in agricultural and forest soils. Some implications for their use as indicators of soil quality. Soil Biol. Biochem. 40, 2146-2155. https://doi.org/10.1016/j.soilbio.2008.03.015.

Triberti, L., Nastri, A., Giordani, G., Comellini, F., Baldoni, G., Toderi, G., 2008. Can mineral and organic fertilization help sequestrate carbon dioxide in cropland?. Eur. J. Agron. 29, 13-20. https://doi.org/10.1016/j.eja.2008.01.009.

Vance, E.D., Brookes, P.C., Jenkinson, D.S., 1987. An extraction method for measuring soil microbial biomass C. Soil Eiol. Biochem 19, 703-707. https://doi.org/10.1016/ 0038-0717(87)90052-6.

Wardle, D.A., Ghani, A., 1995. A critique of the microbial metabolic quotient $\left(\mathrm{qCO}_{2}\right)$ as a bioindicator of disturbance and ecosystem development. Soil Biol. Biochem. 27, 1601-1610. https://doi.org/10.1016/0038-0717(95)00093-T.

Zeglin, L.H., Stursova, M., Sinsabaugh, R.L., Collins, S.L., 2007. Microbial responses to nitrogen addition in three contrasting grassland ecosystems. Oecologia 154, 349-359. https://doi.org/10.1007/s00442-007-0836-6. 